\title{
Valve of the Oval Foramen
}

National Cancer Institute

\section{Source}

National Cancer Institute. Valve of the Oval Foramen. NCI Thesaurus. Code C34326.

A small flap of tissue, which is a remnant of the septum primum, that covers the foramen ovale in the developing fetus. 